\title{
Konsep dan Arah Kebijakan Pemerintah dalam Pembangunan Pertanian di Indonesia
}

\author{
Rahmayandi Mulda \\ Program Studi Ilmu Pemerintahan Fakultas Ilmu Sosial dan Ilmu Politik \\ Universitas Riau Kepulauan, Batam Indonesia \\ rahmayandim@yahoo.co.id
}

\begin{abstract}
The government's policy on development in Indonesia is considered to be impartial in the agriculture sector, from observations, the portion of the budget each year is mostly channeled to other sectors, such as education, health, security and other routine expenditures such as salaries and operations, agriculture is considered very minimal, whereas more than half of the population in Indonesia works in the agricultural sector. The farmers are still complaining about infrastructure problems such as dams, irrigation, and farm roads. In addition, the quality of human resources working in the agricultural sector is still low, the price stability of production is uncertain so that at any time can harm the farmers, the survival of the survivors are allowed by the government when they have great service in encouraging development. The number of problems that occurred in the agricultural sector became the basis of this paper. This research is based on qualitative research, where researchers collect various data field and conduct a deep analysis of the data and on the problems that occur. The conclusion of this research is that government should direct development in agriculture sector so that people get welfare by making policies or regulations that favor the farmers by improving the quality of human resources in the agricultural sector, the availability of facilities and infrastructure, the guarantee of the price of agricultural products and the guarantee of survival farmers.
\end{abstract}

Keywords: policy, government, development, agriculture

\begin{abstract}
Abstrak
Kebijakan pemerintah dalam pembangunan di Indonesia dinilai belum memihak pada sektor pertanian, dari hasil pengamatan, porsi anggaran tiap tahunnya lebih banyak tersalurkan pada sektor-sektor yang lain, seperti pendidikan, kesehatan, keamanan maupun belanja rutin lainnya seperti gaji pegawai dan operasional, sedangkan untuk sektor pertanian dinilai sangat minim, padahal lebih dari setengah jumlah penduduk di Indonesia bekerja di sektor pertanian. Para petani masih banyak mengeluhkan masalah infrastruktur seperti bendungan, irigasi, maupun jalan tani, selain itu kualitas sumber daya manusia yang bekerja disektor pertanian masih rendah, stabilitas harga hasil produksi tidak menentu sehingga sewaktu-waktu dapat merugikan para petani, jaminan kelansungan hidup para petani dibiarkan begitu saja oleh pemerintah padahal mereka punya jasa besar dalam mendorong pembangunan. Banyaknya masalah yang terjadi disektor pertanian tersebut menjadi dasar dari tulisan ini. Penelitian ini didasarkan pada penelitian kualitatif, dimana peneliti mengumpulkan berbagai data dilapangan dan melakukan analisis yang mendalam terhadap data-data maupun pada persoalan-persoalan yang terjadi. Kesimpulan dari penelitian ini adalah pemerintah seharusnya mengarahkan pembangunan pada sektor pertanian sehingga masyarakat mendapatkan kesejahteraan dengan membuat kebijakan atau regulasi yang memihak kepada petani dengan cara peningkatan kualitas sumber daya manusia di sektor pertanian, ketersediaan sarana dan prasarana, jaminan harga hasil produksi pertanian dan jaminan kelangsungan hidup para petani.
\end{abstract}

Kata kunci: kebijakan, pemerintah, pembagunan, pertanian 


\section{PENDAHULUAN}

Perencanaan pembangunan di Indonesia menggariskan bahwa pembangunan yang ideal adalah pembangunan berbasis kerakyatan sebagaimana yang telah diamanatkan dalam konstitusi UUD 1945. Namun dalam realiatas pelaksanaan pembangunan masih jauh dari harapan masyarakat pada umumnya, hal ini terlihat dari gambaran kehidupan masyarakat yang masih banyak hidup ditempat-tempat yang kurang layak, banyaknya masyarakat yang mengadu nasib kenegeri orang karena kehidupan dikampung halaman mereka tak memiliki pekerjaan, dari data statistik menunjukkan jumlah pengangguran masih banyak, dan banyaknya masyarakat mengeluhkan peranan pemerintah dalam menaggulangi kondisi sosial yang mereka alami terutama pada persolan lapangan kerja, kebutuhan pokok dan pembangunan infrastruktur dan suprastruktur yang masih dianggap sangat kurang utamanya pada sektor pertanian.

Bagi Indonesia, apa pun tantangannya, strategi pembangunan pertanian dapat dikatakan berhasil apabila mampu berkontribusi pada peningkatan kesejahteraan masyarakat, sehingga tidak semata berorientasi pada peningkatan produksi fisik sekian macam komoditas pertanian, peternakan, dan perikanan. Kriteria keberhasilan itu seharusnya dapat diukur dari perbaikan tingkat pendapat rumah tangga petani (dan pelaku di sektor lain), peningkatan produktivitas tenaga kerja, serta perbaikan indikator makro seperti pengurangan angka kemiskinan dan pengangguran. (Bustanul Arifin)

Pembangunan pertanian bila dilihat dari segi potensinya adalah sesuatu yang sangat luar biasa karena dari hasil pertanian manusia bisa bertahan hidup. Namun yang menjadi persoalan yang kita hadapi adalah kurangnya pehatian pemerintah baik masalah regulasi undang-undang agraria dan pertanahan maupun pada persoalan pengalokasian anggaran yang belum memadai, selain itu sumber daya manusia yang kurang berkualitas dalam pengelolaan tanah maupun hasil pertanian.

Penduduk Indonesia lebih dari 50 persen bekerja pada sektor pertanian tapi kehidupan para petani masih hidup dibawah tekanan kemiskinan, hal ini menjadi suatu indikator penilaian bahwa pemerintah kurang memperhatikan nasib mereka.

Diskriminasi pembangunan di Indonesia sangat terlihat sangat jelas, dari berbagai sektor publik, pertanian menempati posisi yang kurang mendapat perhatian dari pemerintah, kita lihat dari sektor alokasi anggaran bidang pertanian menempati posisi yang kurang baik. Jika dibandingkan dengan sektor-sektor lain seperti alokasi anggaran untuk pendidikan, 
kesehatan, dan pembangunan industri, dan yang paling parah adalah pengalokasian anggaran untuk sektor belanja pegawai seperti operasional dan gaji pegawai.

Realitas sosial sangat memiriskan kehidupan para petani dimana mereka harus menuggu musim panen tiba selama berbulan-bulan dalam proses panen mereka harus mengorbangkan banyak waktu, tenaga, dan materi sehingga mereka bisa memanen hasil pertanian merekadan terkadang mereka harus menghadapi kegagalan jika musim atau hama tidak bersahabat. Lain halnya bagi sektor yang lain mereka hanya menuggu tiap bulan untuk menerima gaji dari instansi mereka, tanpa harus merasa kawatir.

Hal semacam inilah di mana petani di jadikan sebagai "tumbal" dalam pembangunan di Indonesia. Tanpa harus memperhatikan nasib petani yang berada di garis kemiskinan, dimana pemberdayaan, penyuluhan dan pendampingan untuk para petani masih sangat jarang ditemui di masyarakat. Dalam melihat potret "peran pemerintah dalam peningkatan produksi pertanian" sebagai upaya mensejahterakan masyarakat dalam hal ini adalah para petani yang tinggal di desa-desa yang masih berada pada garis kemiskinan maka dari itu penulis mengcoba mengembangkan pokok permasalahan ini lebih jauh, dalam konteks arah kebijakan pemerintah dalam membangun sektor pertanian sehingga masyarakat yang bekerja di sektor pertanian dan utamanya para petani mendapat perhatian dan jaminan kelangsungan hidup di masa yang akan datang.

\section{KERANGKA TEORI}

Pemerintah berasal dari kata perintah yang berarti menyuruh melakukan sesuatu. Istilah pemerintahan diartikan sebagai perbuatan dalam artian bahwa cara, hal urusan dan sebagainya dalam memerintah, ${ }^{1}$ Secara etimologi, dapat diartikan sebagai "tindakan yang terus menerus (kontinu) atau kebijaksanaan dengan mengunakan suatu rencana maupun akal (rasio) dan tata cara tertentu untuk mencapai tujuan tertentu yang di kehendaki. ${ }^{2}$

Defenisi lain mengartikan bahwa pemerintah ialah jawatan atau aparatur dalam susunan politik. ${ }^{3}$ Pemerintah dalam konteks ini merupakan lembaga yang memiliki kewenagan dalam merumuskan kebijakan dalam mengurus kesejahteraan masyarakatnya.

Salah satu yang menjadi sumber persoalan dalam tata kelola di sektor pertanian ini adalah pemerintah dalam memahami aturan kebijakan dari atas kebawah sering di salah

\footnotetext{
${ }^{1}$ Sri Soemantri Martosoewignjo, System - System Pemerintahan Negara - Negara Asean, Tarsito, Bandung, 1976 Hlm

${ }^{2}$ Utrecht, Pengantar Dalam Hokum Indonesia, Ichtiar Baru, Jakarta, 1986, hlm.28

${ }^{3}$ Muhammad Yamin,Proglamasi Dan Konstitusi, Ghalia Indonesia, Jakarta,1982, hlm. 112
} 
tafsirkan sehingga dalam pelaksanaan kebijakan tersebut menjadi salah arah pembangunannya.Seperti halnya dalam kasus revitalisasi pertanian.Presiden dalam hal ini sebagai pihak pemerintah tampak merasa perlu menerjemahkan strategi yang masih agak abstrak tersebut menjadi langkah kebijakan yang lebih memihak kepada masyarakat bawah (grassroot).Minimal, startegi tersebut mampu dimengerti oleh jajaran birokrasi dari pusat sampai daerah dan dapat dilaksanakan di lapangan.Agenda aksi revitalisasi pertanian ini memerlukan koordinasi yang sebenarnya.Selama ini, masyarakat cukup letih dengan buruknya koordinasi kebijakan di Indonesia, apalagi menyangkut pertanian dalam arti luas yang tersebar di tiga departemen, yaitu sektor pertanian, perkebunan, dan peternakan di departemen pertanian. ${ }^{4}$

Jika kita melihat lebih dalam akan potensi bangsa Indonesia ini dalam hal sumber daya alamnya khususnya di bidang pertanian maka bangsa ini akan sejahtera tapi hal demikian sulit tewujud bila pertanian ini tidak dikelola dengan baik. Meskipun di Indonesia dan negara berkembang lainnya, pembangunan pertanian tidak sesederhana yang diduga. Permasalahan yang paling krusial adalah pasar dan politik sama - sama meminggirkan sektor pertanian dan sektor - sektor lain dengan basis sumber daya alam. Kebijakan ekonomi dan politik sering tidak bersahabat dengan sektor yang amat strategis ini, yang merupakan basis ekonomi rakyat di pedesaan, yang telah menguasai hajat hidup sebagian besar penduduk, menyerap lebih separuh total tenaga kerja bahkan menjadi kutub pengaman pada krisis Indonesia. ${ }^{5}$

Bagi Bangsa Indonesia, pertanian bukan hanya sebagai kegiatan bercocok tanam untuk menghasilkan bahan pangan.Pertanian merupakan bagian dari budaya sekaligus urat nadi kehidupan sebagian besar masyarakatnya.Oleh karena itu tidaklah berlebihan kalau di katakan bahwa maju mundurnya Bangsa Indonesia sangat bergantung pada keberhasilan dalam membangun sektor pertaniannya. ${ }^{6}$

Di negeri ini ada semacam pen"diskriminasi”an dalam pelaksanaan pembangunan yakni dalam sektor pertanian di mana sebagian besar rakyat yang hidup sebagai petani kurang mendapat perhatian dari negara padahal selama ini menjadi landasan pembangunan adalah di sektor pertanian, kenyataan yang mereka hadapi yakni masih bergelut dalam dunia kemiskinan mereka seakan di jadikan "sapi perah" di tengah pembangunan yang telah berlangsung di negeri ini. Namun hal yang sebaliknya di negara - negara maju pertanian

\footnotetext{
${ }^{4}$ Arifin B, Diagnosis Ekonomi Politik Pangan Dan Pertanian, Rajawali Pers, Jakarta, 2007, hlm 23

${ }^{5}$ Arifin B. Analisis Ekonomi Politik Pertanian Indonesia, Kompas, Jakarta, 2004. hlm 17

${ }^{6}$ Bungaran Saragi, dalam Kaman Nainggolan, Kata Pengantar: Pertanian Di Indonesia Kini Dan Esok, 2005Hlm. vii
} 
mendapat perhatian khusus dari pemerintah.Seperti halnya di negara - negara Eropa pertaniannya telah disubsidi oleh pemerintah dengan alasan bahwa pertanian tidak dilihat dari produksi dan dagangannya saja, melainkan dari aspek ketahanan pangan, perlindungan lingkungan dan pembangunan pedesaan. Indonesia ada kecendrungan kuat bahwa sektor pertanian selalu di tuntut untuk menyediakan produksi dengan harga murah dan stabil untuk mengamankan variabel- variabel makro. ${ }^{7}$ Ada berbagai kontribusi pertanian dalam pembangunan ekomomi (Kuznets,1964; Todaro,2000): (1).Pertanian sebagai penyerap tenaga kerja (2).Kontribusi terhadap pendapatan (3).Kontribusi dalam penyediaan pangan (4).Pertanian sebagai penyedia bahan baku (5).Kontribusi dalam bentuk capital (6).Pertanian sebagai sumber devisa.

\section{MOTODE PENELITIAN}

Penelitian ini didasarkan pada penelitian kualitatif, dimana peneliti mengumpulkan berbagai data dilapangan dan melakukan analisis yang mendalam terhadap data-data maupun pada persoalan-persoalan yang terjadi. Dalam menganalisis data yang diperoleh, peneliti akan menggunakan teknik analisis secara deskriptif kualitatif yakni data yang diperoleh akan dianalisis dan disajikan dalam bentuk kata-kata lisan maupun tertulis. Teknik ini bertujuan untuk menggambarkan secara sistematis fakta-fakta dan data data yang diperoleh.Serta hasilhasil penelitian baik dari hasil studi lapang maupun studi literatur untuk kemudian memperjelas gambaran hasil penelitian.

\section{ARAHAN PEMBANGUNAN PERTANIAN}

Bangsa Indonesia sangat dikenal dengan sumber daya alamnya yang melimpah ruah mulai dari rempah-rempah sampai pada minyak bumi yang tersebar dari Sabang sampai Merauke.Bangsa Indonesia merupakan negara agraris, hal ini dapat di lihat dari tanahnya yang subur dengan kekayaan alam yang melimpah ruah dan sebagian besar masyarakatnya hidup dari hasil pertanian. Namun di balik semua itu sebagian besar masyarakatnya masih hidup dibawah garis kemiskinan dan ironisnya dari masyarakat miskin tersebut adalah sebagian besar para petani yang tinggal di desa.

Dari berbagai aspek permasalahan bangsa ini salah satu diantaranya adalah persoalan pertanian. Petani dalam mengelola lahan pertaniananya kurang mendapat perhatian yang serius dari pemerintah. Baik dalam pemberdayaan, pendampingan, maupun penyuluhan di

\footnotetext{
${ }^{7}$ Kaman Nainggolan, Pertanian Indonesia Kini Dan Esok, Pustaka Sinar Harapan, Jakarta, 2005, hlm 2
} 
masyarakat dapat dibilang masih langka kita temui, utamanya para petani yang tinggal di desa, dan bukan hanya masalah yang disebutkan diatas mulai dari sarana sampai pada prasana yang masih sangat terbatas dalam menunjang produktifitas di sektor pertanian tersebut seperti jalanan, bendungan, irigasi, pupuk, bibit, teknologi dan obat-obatan masih mejadi keluhan di masyarakat pada umumnya.

Dari permasalahan yang ada pada sektor pertanian ini jika tidak di tanggapi secara serius oleh pemerintah maka akan menjadi masalah besar yang akan di hadapi oleh bangsa Indonesia karena sektor pertanian menjadi ujung tombak perekonomian di Indonesia, seperti apa yang di ungkapkan oleh mantan Mentri Pertanian Anton Apriyantono bahwa sektor pertanian ini bukan hanya sebagai penyedia kebutuhan pangan bagi penduduknya tetapi juga sekitar 50 persen penduduk hidup dari hasil pertanian. hal yang harus kita sikapi secara serius jika kita ingin melihat masyarakat sejahtera. Namun hal demikian jika kita tidak indahkan maka kehidupan berbangsa kita ini akan selalu berada di garis kemiskinan.

Arah pembangunan bangsa ini akan mengalami banyak hambatan dan masalah, jika tidak punya program pembangunan yang mantap dan berkarakter, dalam artian bahwa pemerintah harus punya visi misi yang sesuai dengan kondisi sosial masyarakat bangsa ini, tanpa harus menjadi bangsa pengekor kenegara lain.

Telah di jelaskan sebelumnya bahwa bangsa Indonesia merupakan negara agraris di mana sebagian besar penduduknya hidup dari hasil pertanian yang mereka kelola, pertanian merupakan tulang punggung dalam pembangunan bangsa ini maka dari itu sektor pertanian ini harus mendapat perhatian lebih serius dari pemerintah, dan jika pemerintah lebih terkonsentrasi pada bidang lain misalnya dalam bidang jasa ataupun industri besar maka dalam melakukan proses pembangunan bangsa ini akan mengalami beberapa masalah karena arah pembangunan yang dilaksanakan kurang sejalan dengan kondisi sosial masyarakat yang ada yakni suatu konsep pembangunan yang tidak sesuai dengan realitas yang ada di negeri ini.

Keseriusan pemerintah dalam membangun sektor pertanian sama halnya membangun ekonomi dan sumber daya manusia yang bekerja disektor pertanian, lebih dari setengah jumlah penduduk Indonesia yang bekerja di sektor pertanian, maka suatu keharusan pemerintah mengarahkan kebijakan pembangunan disektor tersebut. Melihat dari kondisi seperti ini mengambarkan sebuah realitas bahwa sumber daya alam yang melimpah ruah bukanlah sebuah jaminan untuk bisa hidup sejahtera, namun banyak hal yang menjadi faktor untuk membangun sebuah bangsa yang maju salah satunya di antaranya yakni pemerintahan 
yang kuat dan bersih dalam hal ini pemerintah memiliki kemampuan membangun visi misi yang berorientasi pada rakyat di mana setiap kebijakan betul - betul memihak kepada masyarakat.

Di era otonomi daerah sekarang ini bangsa Indonesia dituntut untuk selalu memacu diri dalam meningkatkan kemampuannya untuk mensejahterakan rakyatnya, jika pemerintah dianggap tidak mampu dalam menjalankan tugasnya maka masyarakat akan menuntut pemerintah karena dianggap gagal dalam melaksanakan tugas dan fungsinya tersebut. dalam hal ini pemerintah sebagai regulator atau pemeran penting dalam membangun masyarakat kearah yang lebih baik, maka dari itu di tuntut untuk bekerja lebih baik dan proaktif dalam menjalankan peran dan fungsi dalam hal ini melayani masyarakat.

Dalam program pembangunan nasional sangat penting kirannya memperhatikan adanya pegembangan sumberdaya manusia, guna pencapaian tujuan tersebut. Paradigma pemerintah daerah saat ini di arahkan pada undang-undang nomor 12 Tahun 2008 tentang pemerintah daerah yang mengatur dan mengurus sendiri urusan pemerintah menurut asas otonomi dan tugas pembantuan, dari tujuan ini untuk mempercepat terwujudnya kesejahteraan masyarakat melalui peningkatan pelayanan, pemberdayaan, dan pendampingan masyarakat dalam meningkatkan daya saing daerah.

Melalui pendekatan diatas dapat kita menarik kesimpulan sederhana dalam menyikapi peranan pemerintah dalam pembangunan sebagai upaya mensejahterakan masyarakat terutama dalam peningkatan sumber pendapatan masyarakat desa dalam hal meningkatkan produksi pertanian, dari program ini di butuhkan pemahaman konsep dari setiap aparatur yang terlibat di dalamnya termasuk masyarakat.Sehingga tujuan ynag di harapkan dapat terlaksana.

Berkaitan dengan kebijakan dalam meningkatkan produksi pertanian, dapat dilakukan dengan melakukan pembinaan terhadap pelaku utamanya para petani melalui pemberian berbagai pelatihan, bimbingan, penyuluhan dan pendampingan masyarakat dengan tujuan meningkatkan kompetensinya, termasuk didalamnya mengembangkan inovasi, serta pengenalan teknologi pertanian. Perhatian pemerintah terhadap peningkatan kualitas sumber daya manusia juga sangat penting, pemerintah harus lebih proaktif dalam mengembangkan kemampuan para petani baik dalam memahami kondisi tanah, bibit unggul, pupuk, hama, maupun teknologi pertanian, karena hampir dari semua petani yang ada di Indonesia tidak memiliki background pendidikan sarjana pertanian ataupun sekolah pertanian, mereka hanya bekerja menagandalkan pengalaman dan bekerja secara tradisional. 
Kebijakan atau regulasi pemerintah juga sangat penting jika mampu mengarah pada adanya jaminan kelangsungan hidup para petani, dalam hal ini para petani harus dilindungi, melalui tunjangan hari tua. Para petani memiliki jasa dan kontribusi yang sangat luar biasa dalam mendorong pembagunan maka dari itu pemerintah harus memberi imbalan pada mereka jika tidak mampu lagi bekerja. Jika para pegawai swasta mendapat tunjangan ketika mereka pensiun dari tempat kerja mereka, pegawai negeri sipil masih mendapat tunjangan hari tua karena jasa-jasanya terhadap negara, lalu bagaimana dengan para petani, mereka tidak mendapat jaminan apapun untuk dihari tua mereka. Pemerintah harusnya memberi perlindungan dan kesejateraan kepada petani, jika tidak, masyarakat yang akan bekerja disektor pertanian semakin hari akan semakin berkurang.

Ketersediaan sarana dan prasarana pertanian juga harus menjadi perhatian pemerintah, kita semua tahu, tanah yang ada di Indonesia sangat subur, dan apapun yang di tanam akan bisa tumbuh dengan baik asalkan penanganan yang tepat dan ditunjang teknologi yang tepat. Ketersediaan sarana sangat penting seperti saluran irigasi, bendungan, mesin pengolah tanah maupun jalan-jalan pertanian akan sangat membantu para petani dalam bekerja. Sistem jual beli hasil pertanian juga harus menjadi perhatian serius pemerintah, para petani mengalami kerugian yang cukup besar jika hasil produksi mereka dibeli dengan harga yang sangat murah, mereka membutuhkan waktu berbulan-bulan dalam menghasilkan sebuah produk pertanian (hasil pertanian) namun setelah mereka memanen hasil pertanian mereka harganya jadi turun, mereka sangat dirugikan dari segi waktu, materi, dan tenaga mereka.

Peran pemerintah daerah terhadap peningkatan produksi pertanian ini sama halnya dengan pemerintah pusat adalah bagaimana menumbuhkan dan mengembangkan produksi pertanian dengan menetapkan peraturan perundang-undangan dan kebijakan yang meliputi aspek perlindungan, pendanaan, sarana dan prasarana, informasi pertanian, kemitraan dan dukungan kelembagaan. Adanya otonomi daerah telah menjadikan peran Pemerintah Daerah semakin penting dalam upaya pemberdayaan masyarakat dalam meningkatkan produksi pertaniannya. Dalam hal ini penyesuaian dalam rangka pelaksanaan otonomi daerah sejauh mungkin diupayakan untuk tidak terlepas dari konteks pemberdayaan masyarakat..Dinas Pertanian pada tiap Kabupaten dan Kota menjadi garis terdepan dalam pembinaan pertanian di daerah. Otonomi daerah yang bertujuan untuk mengoptimalkan fungsi pelayanan kepada masyarakat, akan memberikan mandat yang sangat besar kepada salah satu stakeholder di daerah ini. 
Dalam perkembangan daerah yang ada di Indonesia sebagai wilayah otonom dengan beberapa potensi unggulan dan memiliki potensi strategis untuk berkembang menjadi suatu kondisi masyarakat yang sejahtera.Maka untuk itu kesiapan dan kondisi masyarakat yang sadar dan mandiri harus dipersiapkan untuk dapat turut serta berpartisipasi dalam program pembangunan sehingga pemanfaatan sumber daya yang ada di daerah dapat memberikan kesejahteraan bagi masyarakatnya.

Dari temuan dilapangan selama kurun waktu penelitian ini, pemberdayaan kelompok tani lebih banyak terfokus dalam penyediaan sarana dan prasarana pendukung saja sedangkan dalam sisi lainnya masih dinilai kurang memadai terutama dalam upaya mengangkat derajat harkat para petani.

\section{PENUTUP}

Arahan kebijakan pemerintah dalam membangun pertanian di Indonesia yakni ditujukan kepada di sektor pembangunan sumber daya manusia yang berkompoten yang bekerja di sektor pertanian, adanya jaminan hidup bagi para petani utamnya jaminan hari tua, ketersediaan sarana dan prasana yang memadai, adanya regulasi tentang jual beli hasil produksi pertanian dan teknologi yang berbasis pertanian.

\section{DAFTAR PUSTAKA}

Bustanul Arifin, Diagnosis Ekonomi Politik Pangan Dan Pertanian, Rajawali Pers, Jakarta, 2007

Bustanul Arifin,Analisis Ekonomi Politik Pertanian Indonesia, Kompas, Jakarta, 2004.

Bungaran Saragi, dalam Kaman Nainggolan, Kata Pengantar: Pertanian Di Indonesia Kini dan Esok, 2005

Kaman Nainggolan, Pertanian Indonesia Kini Dan Esok, Pustaka Sinar Harapan, Jakarta, 2005

Sri Soemantri Martosoewignjo, System - System Pemerintahan Negara - Negara Asean, Tarsito, Bandung, 1976

Utrecht, Pengantar Dalam Hokum Indonesia, Ichtiar Baru, Jakarta, 1986

Muhammad Yamin,Proglamasi Dan Konstitusi, Ghalia Indonesia, Jakarta,1982 
